\title{
A new mutation of the lamin $A / C$ gene leading to autosomal dominant axonal neuropathy, muscular dystrophy, cardiac disease, and leuconychia
}

\author{
C Goizet, R Ben Yaou, L Demay, P Richard, S Bouillot, M Rouanet, E Hermosilla, G Le Masson, \\ A Lagueny, G Bonne, X Ferrer
}

J Med Genet 2004;41:e29 (http://www.jmedgenet.com/cgi/content/full/41/3/e29). doi: 10.1136/jmg.2003.013383

T he LMNA gene encodes two nuclear envelope proteins, lamins $\mathrm{A}$ and $\mathrm{C}$, derived from alternative splicing. First identified in autosomal dominant Emery-Dreifuss muscular dystrophy (AD-EDMD), ${ }^{1}$ mutations in this gene are implicated in up to seven diseases including autosomal recessive EDMD (AR-EDMD), ${ }^{2}$ limb-girdle muscular dystrophy type IB (LGMDIB), ${ }^{3}$ dilated cardiomyopathy with conduction defects (DCM-CD), ${ }^{4}$ autosomal dominant partial lipodystrophy of Dunnigan type, ${ }^{6}$ autosomal recessive axonal Charcot-Marie-Tooth disease (AR-CMT2), ${ }^{7}$ mandibuloacral dysplasia, ${ }^{8}$ and Hutchinson-Gilford progeria syndrome. ${ }^{9}{ }^{10}$ In addition, some patients appear to have a combination of these different phenotypes ${ }^{11} 12$ or a clinical variant including skin abnormalities. ${ }^{13}$ To extend the clinical spectrum of laminopathies, we report a previously undescribed dominant missense mutation, E33D, identified in LMNA and clinically characterised by the combination of axonal neuropathy with myopathic features, cardiac disease including dilated cardiomyopathy, conduction disturbances and arrhythmia, and leuconychia. The LMNA gene is therefore the first gene implicated in both autosomal dominant and recessive forms of CMT2.

\section{CASE REPORT}

The pedigree of a white family originating from the south west of France is shown in fig 1 . The index case (II-5) and his affected daughter (III-13) were neurologically and cardiologically assessed by one of our team; only partial information was available for other affected members through questioning of patient III-13. The clinical features of all the affected members are shown in table 1 . The results of nerve electrophysiological examination of patients II-5 and III-13 are shown in table 2. A muscle CT scan performed for patient II-5 showed wasting and marked fatty infiltration predominating in paraspinal, vasti, hamstring, and gastrocnemius muscles (fig 2). Fig 3 shows the fingernails of patients II-5 and III-13, exhibiting leuconychia.

Clinical and electrical data are consistent with the diagnosis of autosomal dominant axonal neuropathy (ADCMT2) associated with muscular dystrophy, cardiac disease, and leuconychia in patients II-5 and III-13. Owing to the lack of data this association was not always fully documented for other family members, but a CMT2 phenotype could not be formally excluded in these patients. The variable association of axonal neuropathy, muscular dystrophy, cardiac abnormalities, and leuconychia observed in this family was intriguing. Cardiac disease and/or muscular dystrophy and/or leuconychia are not considered as classical features associated with CMT2. As LMNA gene mutations can result in up to seven diseases affecting specifically nerve, muscle, and/or heart, we subsequently performed DHPLC analysis of the coding region of this gene. ${ }^{14}$ DNA samples for genetic analysis

\section{Key points}

- Mutations of the lamin $A / C$ gene (LMNA) are responsible for up to seven diseases involving muscle, heart, nerve, fat, bone, and skin tissues.

- Until now, only one mutation had been reported, in an autosomal recessive form of axonal Charcot-MarieTooth disease.

- We describe two members of a large family who share clinical features including axonal neuropathy, muscular dystrophy, cardiac disease, and leuconychia. Some of these features were reported in other family members.

- A new LMNA heterozygous missense mutation, E33D, was identified in the two patients.

- To our knowledge, this is the first LMNA mutation to be found in an autosomal dominant form of CMT2, and implies that LMNA is responsible for both autosomal dominant and recessive forms of axonal CharcotMarie-Tooth disease.

were obtained from peripheral blood lymphocytes from two patients (II-5 and III-13) and from one healthy family member (II-14), after their informed consent. DHPLC screening identified a variant of the LMNA exon 1 in the DNA samples of patients II-5 and III-13. Further sequencing of the $L M N A$ exonl identified a heterozygous $99 \mathrm{G} \rightarrow \mathrm{T}$ transition that corresponds to a missense mutation of codon 33, E33D, at the protein level in the DNA of the two patients. This mutation, affecting E33, an amino acid highly conserved through various species and types of lamins (fig 4), was not found in the healthy family member, III-14, nor in 200 healthy unrelated control subjects.

\section{DISCUSSION}

Successive identification of LMNA mutations in seven different entities has dramatically extended the phenotypic spectrum of laminopathies. ${ }^{1-10}$ Cases displaying a combined phenotype of these entities have also been described. ${ }^{11-13}$ The

Abbreviations: $A D-C M T 2$, autosomal dominant Charcot-Marie-Tooth disease; AR-CMT2, autosomal recessive Charcot-Marie-Tooth disease; AD-EDMD, autosomal dominant Emery-Dreifuss muscular dystrophy; $A R-E D M D$, autosomal recessive Emery-Dreifuss muscular dystrophy; $D C M-C D$, dilated cardiomyopathy with conduction defects; LGMDIB, limb girdle muscular dystrophy type 1B 


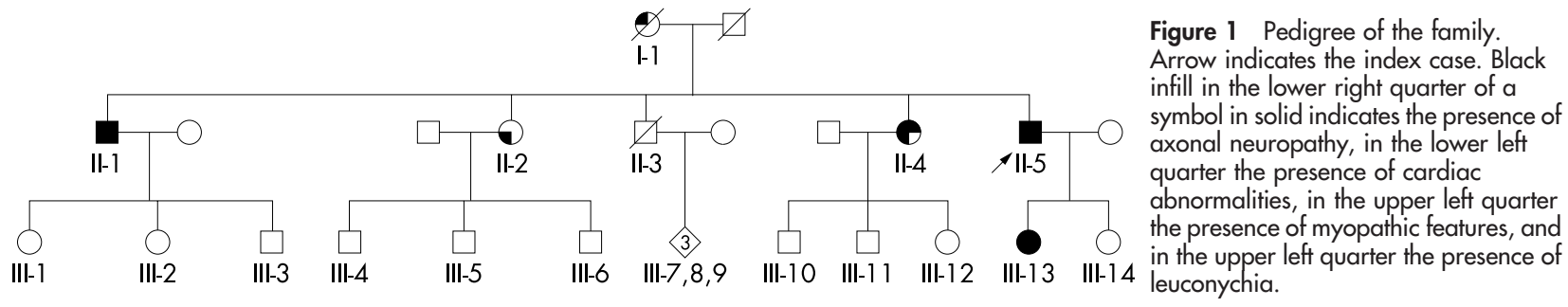

Axonal neuropathy

Myopathic features

Cardiac abnormalites

Leukonychia

Table 1 Clinical features of the affected family members

\begin{tabular}{|c|c|c|c|c|c|c|c|c|c|c|c|c|c|c|}
\hline \multirow[b]{2}{*}{ No. } & \multirow[b]{2}{*}{ Sex } & \multirow[b]{2}{*}{ Onset } & \multirow[b]{2}{*}{$\begin{array}{l}\text { Age at } \\
\text { last exam }\end{array}$} & \multicolumn{2}{|c|}{$\begin{array}{l}\text { Muscle } \\
\text { weakness } \\
\text { and wasting }\end{array}$} & \multicolumn{2}{|c|}{$\begin{array}{l}\text { Sensory } \\
\text { abnormalities }\end{array}$} & \multirow[b]{2}{*}{ Areflexia } & \multirow[b]{2}{*}{ CPK } & \multicolumn{2}{|c|}{$\begin{array}{l}\text { Electrophysiological } \\
\text { examination }\end{array}$} & \multirow[b]{2}{*}{$\begin{array}{l}\text { Muscle } \\
\text { biopsy }\end{array}$} & \multirow[b]{2}{*}{ Heart } & \multirow[b]{2}{*}{ Les } \\
\hline & & & & LL & UL & LL & UL & & & $\begin{array}{l}\text { Nerve } \\
\text { conduction } \\
\text { study }\end{array}$ & $\begin{array}{l}\text { Needle } \\
\text { electromyo- } \\
\text { graphy }\end{array}$ & & & \\
\hline $1-1$ & $\mathrm{~F}$ & - & - & - & - & - & - & - & - & - & - & - & - & $Y$ \\
\hline$\| 11$ & $M$ & Teens & 58 & $\begin{array}{l}\text { Pelvic, } \\
\text { quadriceps }\end{array}$ & $N$ & $\mathrm{~N}$ & $N$ & $\begin{array}{l}\text { Y } \\
\text { (generalised) }\end{array}$ & $\times 2$ & - & $\begin{array}{l}\text { Mixed pattern } \\
\text { (Ш) }\end{array}$ & - & $\begin{array}{l}\text { AF/Normal } \\
\text { echocardiography }\end{array}$ & $Y$ \\
\hline$\|-2$ & $\mathrm{~F}$ & - & - & - & - & - & - & - & - & - & - & - & $\begin{array}{l}\text { Arrhythmia/ } \\
\text { Cardiomyopathy }\end{array}$ & - \\
\hline$\|-4$ & $\mathrm{~F}$ & Juvenile & 50 & $\begin{array}{l}\text { Pelvic, } \\
\text { quadriceps }\end{array}$ & $\mathrm{N}$ & - & - & - & $\times 3$ & - & $\begin{array}{l}\text { Myopathic } \\
\text { pattern (LL) }\end{array}$ & Dystrophic & $\begin{array}{l}\text { Arrhythmia/ } \\
\text { Cardiomyo- } \\
\text { pathy }\end{array}$ & Y \\
\hline II-5 & $M$ & Teens & 55 & $\begin{array}{l}\text { Pelvic and } \\
\text { distal, pes } \\
\text { cavus }\end{array}$ & $\mathrm{N}$ & $\begin{array}{l}\text { Y } \\
\text { (distal) }\end{array}$ & $\mathrm{N}$ & $\begin{array}{l}\text { Y } \\
\text { (generalised) }\end{array}$ & $\times 1.8$ & $\begin{array}{l}\text { Sensorimotor } \\
\text { neuropathy }\end{array}$ & $\begin{array}{l}\text { Neuropathic } \\
\text { pattern }\end{array}$ & Dystrophic & $\begin{array}{l}\text { AF/bradycardia/ } \\
\text { Pacemaker/Normal } \\
\text { echocardiography }\end{array}$ & $Y$ \\
\hline III-5 & $M$ & - & - & - & - & - & - & - & - & - & - & - & $\begin{array}{l}\text { Arrhythmia/ } \\
\text { Cardiomyopathy }\end{array}$ & - \\
\hline III-13 & $3 \mathrm{~F}$ & Teens & 26 & $\mathrm{~N}$ & $N$ & $\begin{array}{l}\text { Y } \\
\text { (distal) }\end{array}$ & $\begin{array}{l}\text { Y } \\
\text { (distal) }\end{array}$ & $\begin{array}{l}\text { Y } \\
\text { (achillean) }\end{array}$ & $\times 6.7$ & $\begin{array}{l}\text { Sensorimotor } \\
\text { neuropathy }\end{array}$ & $\begin{array}{l}\text { Neuropathic } \\
\text { pattern }\end{array}$ & ND & $\begin{array}{l}\text { 1st degree AVB/ } \\
\text { Normal } \\
\text { echocardiography }\end{array}$ & $Y$ \\
\hline
\end{tabular}

ND, not done; CPK, Creatine phosphokinase expressed in number time of upper normal value; -: no data available; UL, upper limbs; LL, lower limbs; Y, presence of abnormality; N, absence of abnormality; AF, atrial fibrillation; $A V B$, atrioventricular block; Leu, leuconychia

new E33D LMNA mutation reported here leads to an original dominantly inherited clinical variant combining axonal neuropathy, muscular dystrophy, cardiac disease, and leuconychia.

So far, only one homozygous LMNA missense mutation, R298C, was reported to be associated with an autosomal form of axonal neuropathy (AR-CMT2) in four families. ${ }^{715}$ Histological features, highly similar to the CMT2 phenotype observed in humans, has also been reported in transgenic LMNA null mice. ${ }^{7}$ Our index case and his affected daughter suffered from a clinically and electrically evident axonal neuropathy, with a less severe course than previously observed,$^{15}$ suggesting that the axonal neuropathy related to LMNA mutation could also be dominantly inherited.

In addition to the CMT2 features, our two patients displayed proximal muscle involvement in the lower limbs.

Table 2 Electrophysiological study of patients II-5 and III-13

\begin{tabular}{|c|c|c|c|c|c|c|c|c|c|c|c|c|c|c|}
\hline & \multicolumn{8}{|c|}{ Motor nerves } & \multicolumn{6}{|c|}{ Sensory nerves } \\
\hline & \multicolumn{2}{|c|}{$\mathrm{MNCV}(\mathrm{m} / \mathrm{s})$} & \multicolumn{2}{|l|}{$\mathrm{DL}$ (ms) } & \multicolumn{2}{|c|}{ CMAP $(\mathrm{mV})$} & \multicolumn{2}{|c|}{$\begin{array}{l}\text { F-wave latency } \\
\text { (ms) }\end{array}$} & \multicolumn{2}{|l|}{ SNCV $(\mathrm{m} / \mathrm{s})$} & \multicolumn{2}{|l|}{$\mathrm{DL}(\mathrm{ms})$} & \multicolumn{2}{|l|}{$\operatorname{SNAP}(\mu \mathrm{V})$} \\
\hline & II-5 & III-13 & II-5 & III-13 & II-5 & III-13 & II-5 & III-13 & II-5 & III-13 & II-5 & III-13 & II-5 & III-13 \\
\hline $\begin{array}{l}\text { Peroneal } \\
\text { (R/L) }\end{array}$ & UR/35.1 & $49 / 54$ & UR/6 & $4.2 / 4.1$ & UR/2* & $7.4 / 6.5$ & UR/UR & UR/UR & ND & 29 & ND & 3.8 & ND & $2.2 \dagger$ \\
\hline Ulnar (L) & 45 & ND & 3.8 & ND & 5.7 & ND & 35.7 & ND & 43.1 & 50.3 & 2.9 & 1.7 & $1.5 \dagger$ & $8.3 \dagger$ \\
\hline $\begin{array}{l}\text { Posterior } \\
\text { tibial }(R / L)\end{array}$ & $\begin{array}{l}32.7 / \\
32.8\end{array}$ & ND/57.7 & $6.1 / 5.4$ & $\mathrm{ND} / 4.9$ & $0.2 / 0.3^{*}$ & ND/8.6 & UR/UR & ND/46 & & & & & & \\
\hline Median (L) & 42.6 & 54.3 & 4.6 & 2.8 & 4.8 & 8.9 & 35 & 28 & & & & & & \\
\hline Sural (R/L) & & & & & & & & & $37.1 / 37.8$ & $31 / 30$ & $3.5 / 3.7$ & $3.5 / 3$ & $3.7 / 3.3 \dagger$ & $1.8 / 2.2 \dagger$ \\
\hline Radial (R/L) & & & & & & & & & $51.9 / 44.2$ & ND/42.9 & $1.8 / 2.4$ & $\mathrm{ND} / 2.1$ & $3.6 / 3.1 \dagger$ & $\mathrm{ND} / 8 \dagger$ \\
\hline
\end{tabular}



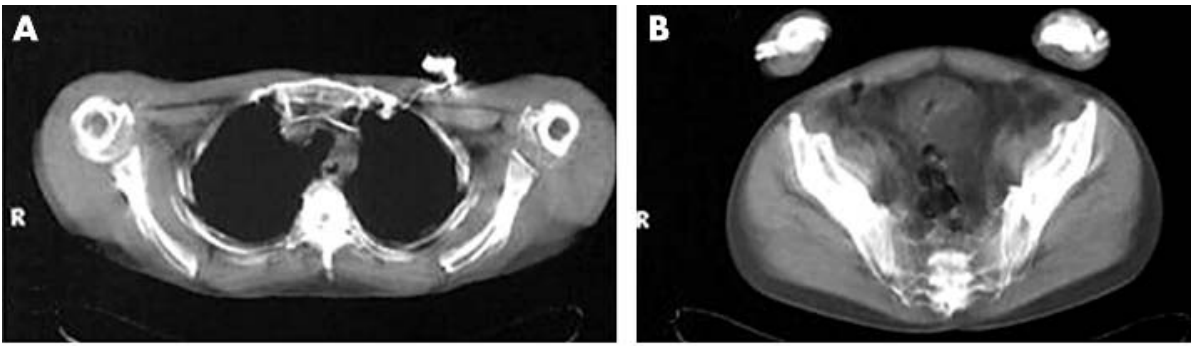

Figure 2 Muscle CT scan of patient II5. Cross section of the scapular girdle (A), pelvic girdle (B), arms (C), thighs (D), forearms and paraspinal muscles $(E)$, and legs (F). Note the selective atrophy and marked fatty infiltration predominating in paraspinal $(*)$, vasti, harmstring $(+)$ and gastrocnemius (§) muscles.
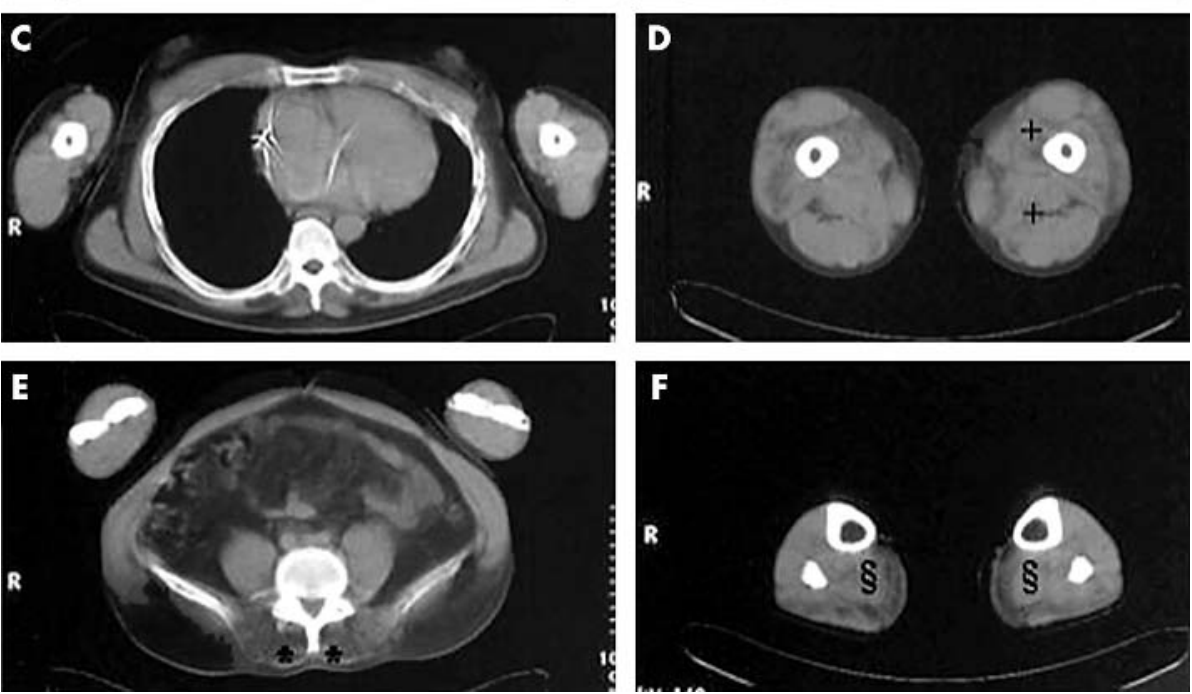

This latter observation can be explained by a probable primary involvement of muscular tissues associated to the nerve degeneration. It is supported in our family by the increased level of serum CPK present in the index case (II-5)
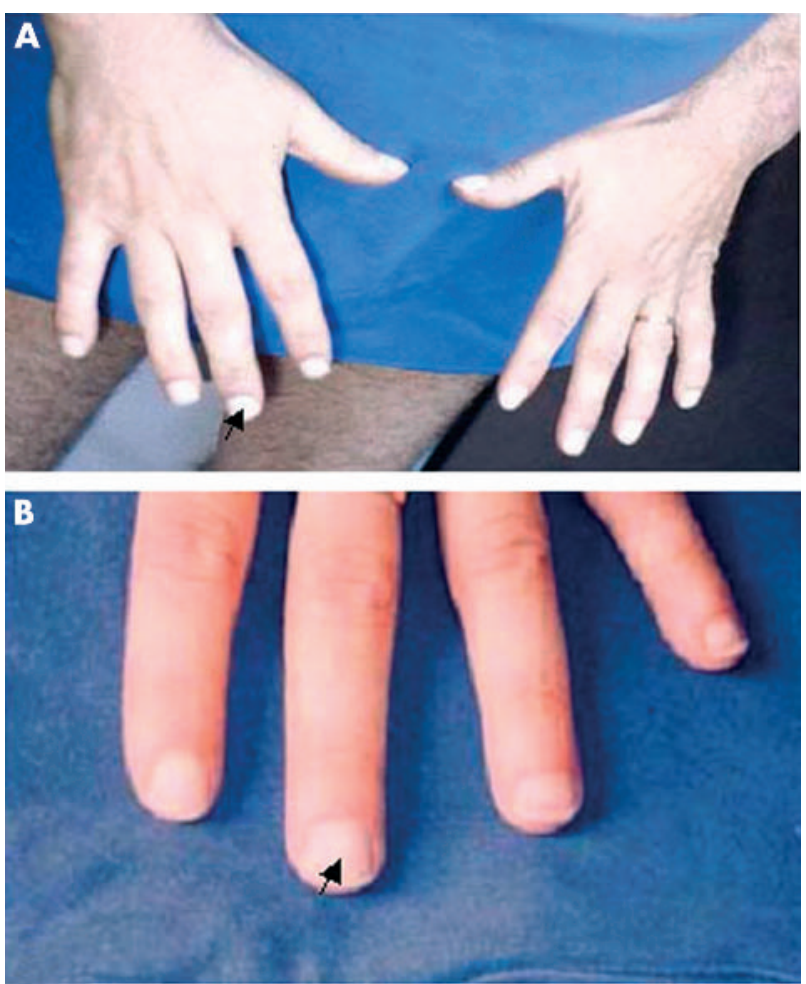

Figure 3 Leuconychia features. Fingernails of index case (A) with complete leuconychia and of his daughter (B) with partial leuconychia starting at the periphery of the fingernails (arrows). and his daughter (III-13), brother, and sister (II-1 and II-4), the dystrophic pattern observed on muscle biopsy of the index case and his sister (II-4), and the muscle CT scan aspect of index case, which shows a predominant fatty infiltration of paraspinal, vasti, harmstring, and gastrocnemius muscles while other muscles in lower limbs were mildly affected. This specific pattern of infiltration is similar to those observed in $\mathrm{AD}-\mathrm{EDMD},{ }^{16}$ and in two cases of laminopathies with a combined phenotype. ${ }^{11}$ This family confirms that muscular and nerve degeneration may occur concomitantly in laminopathies.

Cardiac abnormalities were obvious in our family whereas cardiac investigations remained normal in the families reported by De Sandre et al. ${ }^{7}$ Several authors have described such CMT families with cardiac abnormalities including cardiomyopathy, conduction abnormalities, and rhythm disturbances. ${ }^{17-22}$ Some groups consider this association to be the coincidental occurrence of a relatively common disorder, heart disease, and a less common entity, CMT. ${ }^{20} 22$ In contrast, others suggest that involvements of heart and nerve have a common primary origin. ${ }^{17-1921}$ In a recent review, ${ }^{23}{ }^{24}$ the authors do not consider cardiac disease to be a feature found in CMT2. The cardiac abnormalities reported in the present family are similar to the typical features observed in patients with laminopathies affecting the striated muscle-that is, EDMD, LGMDIB, and DCM-CD, characterised by dilated cardiomyopathy with conduction system disease and rhythm disturbances..$^{2-5} 111214$ Therefore, our family is the first report of a family carrying a LMNA mutation, in which cardiac disease co-segregates with CMT2 features.

Finally, the co-segregation of leuconychia in several affected members of this family is also unexpected, as it has never been reported in patients carrying the LMNA mutation or CMT2 phenotype. Our observation argues for including this feature in the clinical spectrum of laminopathies. It could be included in the group of skin and phaners premature ageing features observed in mandibuloacral dysplasia and Hutchinson-Gilford progeria syndrome. 
Patient lamin $\mathrm{A} / \mathrm{C}$

17 SSTPLSPTRITRLQEKDDLQELNDRL AVYIDRVRSL

human lamin $\mathrm{A} / \mathrm{C}$

mouse lamin $\mathrm{A} / \mathrm{C}$

rat lamin $A$

chicken lamin a

xenopus lamin A

xenopus Lamin IIIA

D. mel lamin Dmo

D. mel lamin C

human Lamin $B 1$

mouse lamin B1

chicken lamin B1

xenopus Lamin IIIB

xenopus Lamin I1

mouse lamin B2

chicken lamin B2

xenopus Lamin II
17 SSTPLSPTRITRLOEKEDLOELNDRL \&VYIDRURSL 17 SSTPLSPTRITRLQEKEDLQELNDRLAVYIDRVRSL 52 17 SSTPLSPTRITRLQEKEDLQELNDRL AVYIDRVRSL 52 16 SGTPLSPTRITRLQEKEDLQELNDRL AVYIDKVRSL 51 12 THTPLSPTRITRLQEKEDLOGLNDRL AVYIDKVRSL 48 16 ACSPGSPTRISRMOEKEDLRHLNDRL A AYIERVRSL 51 39 ASSPLSPTRHSRV AEKVELQNLNDRL ATYIDRVRNL 75 30 ATSPTSPTRTSRQQEKEELOHLNDRLACYIDRNRNL 67

18 PTTPLSPTRLSRLQEKEELRELNDRLAVYIDKVRSL 53 19 PATPLSPTRLSRLQEKEELRELNDRLAVYIDKVRSL 54 17 ASAALSPTRISRLQEKEELRQLNDRLAVYIDKVRSL 52 16 AOSPGSPTRISRHQEKEDLRHLNDRL A YIERVRSL 51 18 MSTPLSPTRITRLQEKVDLQELNDRLALYIDTVRSL 53

1 --TPLSPTRLSRLQEKEELRELNDRLAHYIDRVRAL 45

2 -GTPLSPTRISRLQEKEELRQLNDRL AVYIDRVRAL 46 21 TSTPLSPTRISRLQEKEELRHLNDRLAVYIDRVRAL 56
Figure 4 Amino acid sequences alignment of lamins A, B and C from various species. Divergent amino acids are shaded. The conservation of E33 is presented in bold. Xenopus: Xenopus laevis; D. mel: Drosophila melanogaster.
From the pathophysiological point of view, lamins A amd C are intermediate filaments that localise at the nucleoplasmic surface of the inner nuclear membrane as a meshwork structure, and have multiple interactions with proteins and chromatin. ${ }^{25}$ It has been speculated that the primary defect may have downstream effects on chromatin structure or gene expression, explaining in part the tissue specificity observed in laminopathies. ${ }^{25}$ Despite the growing number of mutations identified in $L M N A$, no clear phenotype-genotype relation has been established. Several mutations affecting amino acids close to E33 have been reported. S22L, R25P, R28W, $\triangle \mathrm{K} 32, \mathrm{~A} 43 \mathrm{~T}, \mathrm{Y} 45 \mathrm{C}, \mathrm{R} 50 \mathrm{P}$, and R50S lead to EDMD of variable severity, DCM-CD or combination of partial lipodystrophy with cardiomyopathy, but no CMT2 features have been observed. ${ }^{12}{ }^{14} 26-28$ Interestingly, a mutation $(98 \mathrm{~A} \rightarrow \mathrm{G}$ ) affecting the same codon and leading to E33G was identified in two patients who had typical EDMD phenotype without any CMT2 features (unpublished data). This illustrates the difficulties in establishing any phenotype-genotype relation. However, the involvement of peripheral nervous system observed in our family probably suggests that E33, like $\mathrm{R} 298$, is functionally important for the nerve tissue. These observations highlight the crucial role of $L M N A$ in the maintenance of peripheral nervous system integrity.

In conclusion, the present cases are the first report of $\mathrm{AD}$ CMT2 due to LMNA mutation. We propose that LMNA should be included in the spectrum of genes responsible for ADCMT2 particularly when associated with proximal muscle involvement, cardiac abnormalities, or leuconychia. Thus, $L M N A$ represents the first gene implicated in both recessive and dominant forms of CMT2.

\section{ACKNOWLEDGEMENTS}

We are grateful to the family members for their participation and cooperation in this study. This study was supported by grants from the European Union Fifth Framework (Myo-Cluster Euromen, contract \#QLGI-1999-00870) and from INSERM/AFM (French rare disease network "EDMD and other nucleopathies", contract \#4MR06F)

\section{Authors' affiliations}

C Goizet, G Le Masson, Service de Neurologie, CHU Pellegrin, Bordeaux, France

R Ben Yaou, G Bonne, Inserm U582, Institut de Myologie, GH Pitié-Salpêtrière, Paris, France
L Demay, P Richard, UF Cardiogénétique et Myogénétique, Service de Biochimie B, GH Pitié-Salpêtrière, Assistance Publique-Hôpitaux de Paris, France

S Bouillot, Laboratoire d'Anatomie Pathologique, CHU Pellegrin, Bordeaux, France

M Rouanet, Service d'Exploration Fonctionnelle du Système Nerveux, CHU Pellegrin, Bordeaux, France

E Hermosilla, A Lagueny, X Ferrer, Service de Neurologie, Hôpital Haut-Lévêque, Pessac, France

Correspondence to: $\operatorname{Dr} C$ Goizet, Service de Neurologie, CHU Pellegrin, Place Amélie Raba-Léon, F-33076 Bordeaux Cedex, France; cyril.goizet@chu-bordeaux.fr

Received 7 October 2003

Accepted 14 October 2003

\section{REFERENCES}

1 Bonne G, Di Barletta MR, Varnous S, Becane H, Hammouda EH, Merlini L, Muntoni F, Greenberg CR, Gary F, Urtizberea JA, Duboc D, Fardeau M, Toniolo D, Schwartz K. Mutations in the gene encoding lamin A/C cause autosomal dominant Emery-Dreifuss muscular dystrophy. Nature Genet 1999:21:285-8.

2 di Barletta MR, Ricci E, Galluzzi G, Tonali P, Mora M, Morandi L, Romorini A, Voit T, Orstavik KH, Merlini L, Trevisan C, Biancalana V, HousmanowaPetrusewicz I, Bione S, Ricotti R, Schwartz K, Bonne G, Toniolo D. Different mutations in the LMNA gene cause autosomal dominant and autosomal recessive Emery-Dreifuss muscular dystrophy. Am J Hum Genet 2000;66:1407-12.

3 Muchir A, Bonne G, van der Kooi AJ, van Meegen M, Baas F, Bolhuis PA, de Visser $M$, Schwartz K. Identification of mutations in the gene encoding lamins $\mathrm{A} / \mathrm{C}$ in autosomal dominant limb girdle muscular dystrophy with atrioventricular conduction disturbances (LGMDIB). Hum Mol Genet 2000;9:1453-9.

4 Fatkin D, MacRae C, Sasaki T, Wolff MR, Porcu M, Frenneaux M, Atherton J, Vidaillet HJ, Spudich S, De Girolami U, Seidman JG, Seidman CE, Muntoni F, Muehle G, Johnson W, McDonough B. Missense mutations in the rod domain of the lamin $A / C$ gene as causes of dilated cardiomyopathy and conductionsystem disease. N Engl J Med 1999;341:1715-24.

5 Bécane H-M, Bonne G, Varnous S, Muchir A, Ortega V, Hammouda EH, Urtizberea J-A, Lavergne T, Fardeau M, Eymard B, Weber S, Schwartz K, Duboc D. High incidence of sudden death with conduction system and myocardial disease due to lamins $\mathrm{A}$ and $\mathrm{C}$ gene mutation. Pacing Clin Electrophysiol 2000;23:1661-6.

6 Shackleton S, Lloyd DJ, Jackson SN, Evans R, Niermeijer MF, Singh BM, Schmidt H, Brabant G, Kumar S, Durrington PN, Gregory S, O'Rahilly S, Trembath RC. LMNA, encoding lamin A/C, is mutated in partial lipodystrophy. Nature Genet 2000;24:153-6.

7 De Sandre-Giovannoli A, Chaouch M, Kozlov S, Vallat JM, Tazir M, Kassouri N, Szepetowski P, Hammadouche T, Vandenberghe A, Stewart CL, Grid D, Levy N. Homozygous defects in LMNA, encoding lamin A/C nuclearenvelope proteins, cause autosomal recessive axonal neuropathy in human (Charcot- Marie-Tooth Disorder Type 2) and mouse. Am J Hum Genet 2002;70:726-36. 
8 Novelli G, Muchir A, Sangiuolo F, Helbling-Leclerc A, Rosaria d'Apice M Massart C, Capon F, Sbraccia P, Federici M, Lauro R, Tudisco C, Pallota R, Scarano G, Dallapiccola B, Merlini L, Bonne G. Mandibuloacral dysplasia is caused by a mutation in LMNA encoding lamins $A / C$. Am J Hum Genet 2002:71:426-31.

9 De Sandre-Giovannoli A, Bernard R, Cau P, Navarro C, Amiel J, Boccacio I, Lyonnet S, Stewart CL, Munnich A, Le Merrer M, Levy N. Lamin A truncation in Hutchinson-Gilford progeria. Science 2003;300:2055.

10 Eriksson M, Brown WT, Gordon LB, Glynn MW, Singer J, Scott L, Erdos MR, Robbins CM, Moses TY, Berglund P, Dutra A, Pak E, Durkin S, Csoka AB, Boehnke M, Glover TW, Collins FS. Recurrent de novo point mutations in lamin A cause Hutchinson-Gilford progeria syndrome. Nature 2003 25:25.

11 van der Kooi AJ, Bonne G, Eymard B, Duboc D, Talim B, Van der Valk M, Reiss P, Richard P, Demay L, Merlini L, Schwartz K, Busch HF, de Visser M. Lamin A/C mutations with lipodystrophy, cardiac abnormalities, and muscular dystrophy. Neurology 2002;59:620-3.

12 Garg A, Speckman RA, Bowcock AM. Multisystem dystrophy syndrome due to novel missense mutations in the amino-terminal head and alpha-helical rod domains of the lamin A/C gene. Am J Med 2002;1 12:549-55.

13 Caux F, Dubosclard E, Lascols O, Buendia B, Chazouilleres O, Cohen A, Courvalin JC, Laroche L, Capeau J, Vigouroux C, Christin-Maitre S. A new clinical condition linked to a novel mutation in lamins $A$ and $C$ with generalized lipoatrophy, insulin-resistant diabetes, disseminated leukomelanodermic papules, liver steatosis, and cardiomyopathy. J Clin Endocrinol Metab 2003;88:1006-13.

14 Bonne G, Mercuri E, Muchir A, Urtiziberea A, Becane HM, Reca D, Merlini L, Wehnert M, Boor R, Reuner U, Vorgerd M, Wicklein EM, Eymard B, Duboc D, Penisson-Besnier I, Cuisset JM, Ferrer X, Desguerre I, Lacombe D, Bushby K, Pollitt C, Toniolo D, Fardeau M, Schwartz K, Muntoni F. Clinical and molecular genetic spectrum of autosomal dominant Emery Dreifuss muscular dystrophy due to mutations of the lamin A/C gene. Ann Neurol 2000:48:170-80

15 Chaouch M, Allal Y, De Sandre-Giovannoli A, Vallat JM, Amer-el-Khedoud A Kassouri N, Chaouch A, Sindou P, Hammadouche T, Tazir M, Levy N, Grid D. The phenotypic manifestations of autosomal recessive axonal Charcot- MarieTooth due to a mutation in lamin A/C gene. Neuromuscul Disord 2003; 13:60-7

16 Mercuri E, Counsell S, Allsop J, Jungbluth H, Kinali M, Bonne G, Schwartz K Bydder G, Dubowitz V, Muntoni F. Selective muscle involvement on magnetic resonance imaging in autosomal dominant Emery-Dreifuss muscular dystrophy. Neuropediatrics 2002;33:10-14.

17 Leak $\mathrm{D}$. Paroxysmal atrial fibrillation in peroneal muscular atrophy. $\mathrm{Br} \mathrm{Heart} J$ 1961;23:326-8.

18 Littler W. Heart block and peroneal muscular atrophy. A family study. Q J Med 1970;39:431-40

19 Bowers D. Charcot-Marie-Tooth disease, Wolff-Parkinson-White syndrome, and abnormal intracardiac conduction. Am Heart J 1973;86:535-8.

20 Isner JM, Hawley RJ, Weintraub AM, Engel WK. Cardiac findings in CharcotMarie-Tooth disease. A prospective study of 68 patients. Arch Intern Med 1979;139:1161-5.

21 Lowry PJ, Littler WA. Peroneal muscular atrophy associated with cardiac conducting tissue disease: further observations. Postgrad Med $J$ 1983;59:530-52

22 Dyck PJ, Swanson CJ, Nishimura RA, Kazmier FJ, Lie JT. Cardiomyopathy in patients with hereditary motor and sensory neuropathy. Mayo Clin Proc 1987;62:672-5.

23 Workshop report. 2nd Workshop of the European CMT Consortium: 53rd ENMC International Workshop on Classification and Diagnostic Guidelines for Charcot-Marie-Tooth Type 2 (CMT2-HMSN II) and Distal Hereditary Motor Neuropathy (distal HMN-Spinal CMT) 26-28 September 1997, Naarden, The Netherlands. Neuromuscul Disord 1998;8:426-31.

24 Gemignani F, Marbini A. Charcot-Marie-Tooth disease (CMT): distinctive phenotypic and genotypic features in CMT type 2. J Neurol Sci 2001; 184:1-9.

25 Hutchison CJ. Lamins: building blocks or regulators of gene expression? Nat Rev Mol Cell Biol 2002;3:848-58.

26 Pethig K, Peters T. LMNA mutations in cardiac transplant recipients with familial dilated cardiomyopathy. Circulation 2001;104(Suppl II): 17.

27 Brown CA, Lanning RW, McKinney KQ, Salvino AR, Cherniske E, Crowe CA, Darras BT, Gominak S, Greenberg CR, Grosmann C, Heydemann P, Mendell JR, Pober BR, Sasaki T, Shapiro F, Simpson DA, Suchowersky O, Edward Spence J. Novel and recurrent mutations in lamin A/C in patients with Emery-Dreifuss muscular dystrophy. Am J Med Genet 2001;102:359-67.

28 Vytopil M, Ricci E, Dello Russo A, Hanisch F, Neudecker S, Zierz S, Ricotti R, Demay L, Richard P, Wehnert M, Bonne G, Merlini L, Toniolo D. Frequent low penetrance mutations in the lamin A/C gene, causing Emery Dreifuss muscular dystrophy. Neuromuscul Disord 2002;12:958-63. 